\author{
В. Лихогляд, \\ аспірантка кафедри міжнародного права \\ Інституту міжнародних відносин \\ Київського національного університету імені Тараса Шевченка
}

\title{
НЕДОТРИМАННЯ МІЖНАРОДНИХ СТАНДАРТІВ ЗАХИСТУ ЕКОЛОГІЧНИХ ПРАВ ЛЮДИНИ У СПРАВАХ ЩОДО УКРАЇНИ В РАМКАХ ОРХУСЬКОЇ КОНВЕНЦІЇ ТА КОНВЕНЦІЇ ЕСПО
}

Постановка проблеми. Екологічні права людини поділяються на матеріальні та процесуальні. До першої групи відносять право на сприятливе (здорове, адекватне, безпечне) навколишнє середовище, а також інші права, наприклад, право на чисту воду, право на безпечні харчові продукти тощо. До другої групи відносять право на доступ до інформації, участь у процесі прийняття рішень та доступ до правосуддя у сфері охорони довкілля. В міжнародному договірному праві зазначені процесуальні права було закріплено в Орхуській конвенції про доступ до інформації, участь громадськості в процесі прийняття рішень та доступ до правосуддя з питань, що стосуються навколишнього середовища, 1998 р. (далі Орхуська конвенція) та Конвенції про оцінку впливу на навколишнє середовище у транскордонному контексті (Конвенція Еспо). Саме на міжнародних стандартах захисту цієї групи прав ми й зосередимо свою увагу. Останнім часом в Україні значно погіршилися основні показники стану навколишнього середовища. Очевидним постає питання дотримання прав на доступ до екологічної інформації, на участь у публічних слуханнях з питань впливу запланованої діяльності на довкілля. Зрозуміло, що аналогічні питання стоять на порядку денному для майже кожної держави світу, проте міжнародне співтовари- ство не зможе розв'язати ці глобальні проблеми без максимальної підтримки окремих держав. Для цього розроблені різноманітні інструменти міжнародного права, дотримання яких кожною державою допоможе у майбутньому більш ефективно долати глобальні екологічні проблеми.

Стан опрацювання ціеї проблематики. Питання міжнародних стандартів захисту екологічних прав грунтовно вивчалось у працях В. Андрейцева, П. Бірюкова, Б. Буркинського, С. Кравченко, М. Краснової, С. Лисовського, Н. Малишевої, М. Медведєвої, В. Мицика, В. Рачинської, А. Солнцева, Ю. Шемшученка та інших.

Метою статті $€$ висвітлення характерних випадків недотримання захисту екологічних прав людини в Україні, які стали причиною для визнання України порушником Орхуської конвенції (на деякий час) та Конвенції Еспо.

Виклад основного матеріалу. Право на сприятливе навколишнє середовище визнається одним з основних прав людини, проте це право отримало визнання та було закріплено лише на галузевому рівні. Тому Україна ратифікувала понад 40 міжнародних екологічних конвенцій. Основним міжнародним актом, який повинен сприяти захисту права на сприятливе для здоров'я та добробуту навколишнє середовище, гарантувати доступ до інформації, участь 
громадськості в процесі прийняття рішень і доступ до правосуддя в екологічних справах, є Орхуська конвенція, яку Україна ратифікувала 6 липня 1999 року. Положення Конвенції $€$ нормами прямої дії, національне законодавство може їх конкретизувати в аспекті процедур і механізмів судового захисту порушених екологічних прав та інтересів [1].

У свою чергу, Конвенція Еспо - це міжнародний договір, який зобов'язує держави проводити оцінку впливу на навколишнє середовище різноманітних проєктів у випадку, коли вони можуть вплинути на навколишне середовище іншої держави. Метою Конвенції $є$ запобігти значному шкідливому транскордонному впливу як результату запланованої господарської діяльності, а також сприяти його зменшенню і контролю за ним. Конвенція Еспо є першою багатосторонньою угодою, яка закріпила екологічні процедурні права та обов'язки Сторін стосовно транскордонного впливу діяльності, що планується. Конвенція встановлює зобов'язання Сторін щодо оцінки впливу ще на етапі планування. Передбачаються також заходи з попередження, контролю та мінімізації будь-якого впливу на навколишнє середовище.

Конвенція Еспо має на меті сприяти забезпеченню сталого розвитку засобами заохочення міжнародної співпраці у справі оцінки ймовірного впливу планованої діяльності на навколишнє середовище. Цей міжнародний договір спрямований на запобігання, мінімізацію наслідків та організації екологічного моніторингу впливу на навколишнє середовище [2].

У Конвенції Еспо міститься зобов'язання держави походження повідомити зачеплену державу про заплановану діяльність, яка може спричинити негативні наслідки для навколишнього середовища цієї держави (ст. 3). Цей міжнародний договір передбачає обов'язок держави, яка планує діяльність, що може мати негативний вплив на навколишнє середовище інших держав, повідомити їх про це, надати необхідну документацію, провести консультації та переговори з цих питань, проінформувати громадськість та врахувати думку протилежної сторони [3]. Порушення зазначених процедурних вимог стало підставою для ініціювання проти України справ у комітетах 3 питань недотримання Конвенції Еспо та Орхуської конвенції з приводу будівництва нашою державою глибоководного судового каналу «Дунай - Чорне море» в українській частині дельти Дунаю [4, с. 336].

Оскільки ця справа є характерним прикладом порушення положень одразу двох важливих міжнародних екологічних договорів Україною, варто надати детальний iї опис.

Справа про канал Бистре між Румунією (постраждала сторона) та Україною (сторона походження) стосується проєкту «Глибоководна навігація каналу "Дунай - Чорне море» через гирло Бистре» [5]. Цей навігаційний канал з’єднує Дунай 3 Чорним морем. Канал існував і раніше, але його потрібно було оновити, щоб використовувати знову.

Проєкт підпадав під дію статті 1 (V) 17 та пункту 9 Додатка I до Конвенції Еспо («внутрішні водні шляхи та порти для руху внутрішніми водними шляхами, що дозволяють прохід суднам понад 1350 тон») [3]. Він був розділений на дві окремі фази: фаза I та фаза II, кожна з яких підлягала різній державній екологічній експертизі. Процедура надання дозволу на впровадження I фази була розпочата в 2002 році. Україна повідомила Румунію про проєкт без дотримання всіх вимог Конвенціі Еспо. Остаточне рішення було прийнято у квітні 2004 року, і роботи розпочалися наступного місяця [6].

Уряд України надав Румунії звіт про оцінку впливу на довкілля (звіт про ОВД) стосовно фази I лише 
5 серпня 2004 року - через декілька місяців після прийняття остаточного рішення та початку робіт. Звіт повинен був стати основою для двосторонніх консультацій щодо потенційного транскордонного впливу запланованої діяльності та заходів щодо зменшення або усунення іï впливу. Очевидно, що ці консультації мали відбутися до прийняття остаточного рішення. Незважаючи на той факт, що уряд Румунії зв'язався 3 урядом України та кілька разів наголошував на необхідності консультацій, передбачених Конвенцією, Україна не виконала всі необхідні процедури.

До отримання звіту про ОВД, але після початку впровадження Фази I, а саме 26 травня 2004 р. Румунія подала заяву щодо цієї справи до Комітету з імплементації - спеціального органу, який займається моніторингом дотримання процедури відповідності Конвенції Еспо.

Оскільки Україна заперечувала, що проєкт матиме суттєві негативні наслідки для транскордонного впливу на навколишнє середовище, що означало б, що в цьому випадку Конвенція Еспо не застосовується, Румунія хотіла створити слідчу комісію для розслідування цієї справи та пошуку відповіді на питання, чи може проєкт мати такий вплив чи ні.

Остаточний висновок слідчої комісіі, відповідно до статті 3 , пункту $7 \mathrm{KoH}-$ венції, визначив, що проєкт, ймовірно, матиме значний несприятливий транскордонний вплив. У такій ситуації вимоги Конвенції Еспо мали дійсно застосовуватися до цього проєкту, і слідча комісія постановила, що Румунію слід розглядати як «постраждалу сторону» [7].

Комітет 3 імплементації вважав, що впровадження проєкту має зупинитися до надання висновку слідчої комісіі. Він також дійшов висновку, що це рішення має бути обов'язковим 3 моменту прийняття, і не має ретроспективної діі. Таким чином, Україна повинна повідомити Румунію та вжити інших необхідних заходів відповідно до Конвенції Еспо.

Однак на цьому етапі Україна обмежилася запевненням, що «весь проєкт проводитиметься відповідно до відповідних міжнародних зобов'язань». У наступному році у листі до виконавчого секретаря ЄЕK ООН, від 30 травня 2007 р., Україна заявила, що вона «ще вивчає питання, підняті в остаточному висновку слідчої комісії, продовжуючи реалізацію фази I.

Тим часом у 2004 р. Україна розпочала фазу II проєкту. Звіт про ОВД було надано у 2006 р. Звіт заперечував значний несприятливий транскордонний вплив та не відповідав деяким іншим вимогам Конвенції Еспо. Офіційне повідомлення було подане Румунії лише 24 квітня 2007 року, через 10 місяців після остаточного висновку слідчої комісіі. Крім того, повідомлення не відповідало вимогам Конвенції Еспо, бо не згадувало про «характер можливого рішення» (як того вимагає ст. 3, абз. 2 Конвенціï Еспо). Звіт про ОВД було подано Румунії пізніше. Румунію та іiі громадськість не просили висловити свої коментарі, не відбулось й консультацій між Україною та Румунією.

Рішення про дозвіл на впровадження фази II було прийняте Кабінетом Міністрів України (30 травня 2007 р.). Врешті-решт, Україна надіслала уряду Румунії остаточне рішення, прийняте 28 грудня 2007 р. [8].

Під час четвертого засідання Наради Сторін, (Бухарест, 19-21 травня 2008 р.), вона визнала, що факт впровадження фази I не вважається таким, що на той час чітко не відповідав положенням Конвенції Еспо, оскільки Україна вважала, що проєкт, швидше за все, не буде мати значний несприятливий транскордонний вплив.

Однак, оскільки Україна продовжила реалізацію проєкту після того, як питання було передано на розслідування та без проведення транскордонної процедури, Комітет з імплементації дотримувався думки, що тим 
самим Україна проігнорувала предмет та мету процедури розслідування.

Отже, Україна не дотримувалась вимог Конвенції Еспо стосовно забезпечення належної участі румунських органів влади та громадськості у відповідних процедурах з ОВД. Зокрема, Україна не повідомила Румунію, як передбачалося у ст. 3, абз. 2 Конвенції Еспо; не подала інформацію згідно зі ст. 3, абз. 5 (а); не вживала заходів, щоб разом із Румунією забезпечити, щоб громадськість Румунії, що проживає в районах, які можуть постраждати, була проінформована, як це вимагається ст. 3, абз. 8; не надала, відповідно до ст. 4, абз. 2 та ст. 2, абз. 3, документацію про ОВД Румунії для прийняття рішення; не вживала заходів, щоб спільно з Румунією розповсюдити документацію про ОВД для румунської громадськості, як потрібно згідно зі ст. 4, абз. 2 ; не мала консультації з Румунією щодо потенційного транскордонного впливу та заходів щодо зменшення або усунення такого впливу, як вимагає ст. 5, і не вжила заходів, щоб домовитись з Румунією про часові рамки для таких консультацій, як це також вимагається ст. 5; не гарантувала, що остаточне рішення про дозвіл на впровадження фази I врахувало результати консультацій 3 Румунією, як того вимагає ст. 6, абз. 1; не надала Румунії текст остаточного рішення про дозвіл на впровадження фази I, а також причини та міркування, на яких вона базувалася, як вимагається ст. 6, абз. 222 [8].

За підсумками четвертого засідання Наради Сторін, опубліковано декларацію про невиконання урядом України вимог Конвенції. Уряд України має зупинити роботи, скасувати остаточне рішення та вжити заходів для дотримання відповідних положень Конвенції Еспо. Україна має також прийняти стратегію імплементації Конвенції Еспо в українське законодавство; прийняти нові закони, що задовольняють вимоги Конвенції Еспо.
Україна виконала вимогу стосовно ведення переговорів з сусідніми кранами щодо співпраці у виконанні Конвенції Еспо. Також, Україна надіслала Румунії документацію щодо ОВД проєкту; взяла участь у консультаціях з громадськістю Румунії 9 червня 2009 року; організувала зустріч 3 румунською стороною в Києві 15-16 липня 2009 р., де були обговорені подані коментарі до проєкту.

Однак роботи щодо обох фаз були продовжені. Хоча Україна прийняла стратегію імплементації Конвенції, актуальні зміни в законодавстві не відповідали стратегії [9].

П'яте засідання Наради Сторін визнало, що Україна не виконала деякі свої зобов'язання відповідно до Рішення IV / 2 щодо обох фаз. Нарада Сторін також звернулася 3 проханням до України щороку звітувати про заходи, спрямовані на приведення Проєкту в повну відповідність з Конвенцією, зокрема щодо реалізації стратегії конкретних законодавчих заходів, прийнятих з цією метою [10].

На шостій Нараді Сторін Конвенції Еспо у 2014 році зазначено, що не було вжито жодних кроків для реалізації Конвенції. На сьомій Нараді Сторін Конвенції Еспо у 2017 році - надана Україною інформація про кроки, які робляться для приведення проєкту каналу по гирлу Бистре у відповідність до Конвенціі, є неповною [11].

У 2020 році на восьмій Нараді Сторін Конвенції Еспо було відмічено, що Україна прийняла підзаконні акти по здійсненню Конвенції та реалізації різних кроків, перерахованих в «дорожній карті», включаючи проведення оцінки збитку навколишньому середовищу в результаті робіт під час I і II фаз проекту будівництва каналу «Бистре» i розробку проєкту плану компенсаційних або пом'якшувальних заходів; уряд також приступив до розробки нового проєкту зі створення суднового ходу «Бистре», і відповідно до Конвенції повідомив про це Румунію. Румунія підтвердила свій намір 
брати участь в передбаченій Конвенцією транскордонній процедурі щодо нового проєкту зі створення суднового ходу «Бистре» і свою готовність тісно співпрацювати з Україною щодо оцінки шкоди навколишньому середовищу і розробки компенсаційних або пом'якшувальних заходів. Проте, незважаючи на досягнутий прогрес, Україна досі не виконала всі свої зобов'язання по рішеннях IV / $2, \mathrm{~V} / 4$, VI/2 i IS/1f. Тому Нарада Сторін не скасувала застереження, винесене уряду України на його четвертому засіданні [12].

Паралельно відбувався розгляд цієї справи у Комітету з питань дотримання Орхуської конвенції. У 2004 р. Румунія подала до нього скаргу із приводу недотримання Україною іï положень під час будівництва каналу "Дунай Чорне море» через гирло Бистре. На другій Нараді Сторін у 2005 році було прийнято рішення II / 5b, яке містило такі положення: Україна порушила положення статті 6 щодо участі громадськості в прийнятті рішень 3 конкретних видів діяльності; не забезпечила того, щоб відповідальні державні органи, після отримання відповідних доповідей, надавали інформацію, у порушення статті 4 Конвенції; в сукупності ці фактори свідчать про відсутність необхідних законодавчих, регулятивних та інших заходів, необхідних для виконання положень цієї Конвенції у порушення статті $3 \mathrm{KoH}-$ венції.

Відповідно, Нарада Сторін рекомендувала Україні гармонізувати законодавство та практику 3 положеннями Конвенції і включити у свою наступну доповідь дані про заходи, вжиті з цією метою; а також рекомендувала Україні надати до Комітету 3 питань дотримання стратегію імплементації положень Конвенції в національне законодавство i розробки практичних механізмів та відповідних підзаконних актів [14]. На Третій Нараді Сторін було ухвалено рішення III / 6f, у якому знову було наголо- шено, що Україна не дотримується положень даної Конвенції; запропоновано уряду України необхідну допомогу для виконання своїх зобов'язань [15]. План дій, затверджений Розпорядженням КМУ від 27 грудня 2008 року № 1628-р, надійшов до Комітету вчасно, тому питання щодо санкцій було тимчасово знято [16]. Рішенням 2011 р. до України було застосовано санкції у формі попередження. Воно могло бути зняте у 2012 р., якщо Україна виконає необхідні умови, зазначені в рішенні Наради Сторін II/5b, повідомить про це секретаріат і надасть усі необхідні докази до 1 квітня 2012 р [13, с. 50].

Зрештою, у випадку з порушенням саме цієї Конвенції за цією справою, Україна отримала позитивний висновок. Так, за підсумками шостої Наради Сторін Орхуської конвенції, Україну було виключено зі списку порушників цієї конвенції, оскільки вона виконала домашнє завдання, прийнявши закон «Про оцінку впливу на навколишнє середовище». Комітет із дотримання вимог Орхуської конвенції проаналізував текст цього закону, і прийшов до висновку, що його положення повністю задовольняють всі рекомендації Наради Сторін щодо України [17].

Варто додати, що сьогодні в Україні реалізується ще декілька проєктів у ядерній сфері, які потенційно підпадають під дію Конвенції Еспо і потребують пошуку шляхів забезпечення дотримання Конвенції Еспо. Серед них можна окремо виділити:

- спорудження 3 та 4 реакторів Хмельницької AEC;

- спорудження заводу з виробництва ядерного палива;

- продовження експлуатації енергоблоків № 1, 2 Рівненської АЕС [18].

Детально зупинимось на останньому проєкті. 18 січня 2005 р. Державна компанія «Енергоатом» (оператор атомних електростанцій в Україні) прийняла Робочий план 3 впровадження комплексної програми робіт з продовження терміну експлуатації 
діючого енергоблоків атомних електростанцій.

У 2005-2010 рр. було здійснено численні кроки з боку оператора, «Енергоатома», та Державного комітету ядерного регулювання (сьогодні - Державна інспекція з ядерного регулювання), які включали як заходи безпеки, реалізовані оператором, так і різні проміжні рішення, прийняті Державним комітетом ядерного регулювання щодо 1-го та 2-го реакторів Рівненської АЕС. 10 грудня 2010 року відбулося засідання Державного комітету ядерного регулювання безпосередньо на Рівненській АЕС. Колегія прийняла рішення №15 від 10 грудня 2010 року про видачу Енергоатому нової ліцензії на експлуатацію ядерних реакторів № 1 та № 2 Рівненської АЕС на строк до 31 грудня 2031 р.

У 2011 році міська молодіжна громадська організація «Екоклуб» подала до Комітету 3 імплементації Конвенції Еспо скаргу, у якій стверджувала, що Україна порушила пункт 2 статті 2 та разом зі статтями 3-6 Конвенції Еспо, не застосувавши положення Конвенції Еспо до процедури видачі дозволу для продовження терміну експлуатації 1-го та 2-го ядерних реакторів на Рівненській AEC; а також порушила пункт 2 статті 2 , не надавши звіт про ОВД до видачі дозволу на продовження терміну експлуатації ядерних реакторів [19].

Під час Шостої Наради Сторін Конвенції Еспо у 2014 році було вирішено продовжити розгляд справи щодо подальшої експлуатації енергоблоків № 1 та 2 Рівненської АЕС і розглянути інформацію про практику експлуатації AEC в інших країнах із залученням експертів МАГАТЕ, яку має надати Україна на розгляд Комітету з дотримання Конвенції Еспо.

Дане рішення дозволило уникнути винесення попередження Уряду України щодо недотримання Конвенції Еспо, а також відтермінувало розгляд питання продовження екс- плуатації енергоблоків № 1, 2 Рівненської AEC на більш пізній термін. Це надало можливість Україні залучити до розгляду питання експертів з атомної енергетики, а Комітету з дотримання врахувати досвід інших країн при дотриманні Конвенції Еспо [20].

Під час Сьомої Наради Сторін Конвенції Еспо у 2017 році, було відмічено, що Україна не зробила необхідних практичних кроків для приведення проєкту у відповідність 3 Конвенцією. Україні запропоновано до кінця 2018 року переглянути іï рішення про продовження терміну експлуатаціі енергоблоків № 1 і № 2 Рівненської AEC на основі результатів ОВД, яка повинна здійснюватися відповідно до Конвенції [21]. Поки що позитивне рішення щодо України по цій справі відсутне.

Отже, розгляд справ проти України засвідчує, що, беручи на себе міжнародно-правові зобов'язання, держава повинна оцінити власні можливості щодо їх впровадження у внутрішню правову систему, включаючи забезпечення ефективного контролю за дотриманням положень багатосторонніх природоохоронних угод фізичними та юридичними особами, які перебувають під іiі юрисдикцією. Деякі вітчизняні експерти критикують розгляд справ у рамках Орхуської конвенції та Конвенції Еспо через те, що економічні й політичні чинники переважають, на їхню думку, над правовими. Залишаючи осторонь усі аргументи української сторони, наприклад, щодо доцільності проєкту з відновлення глибоководного суднового каналу по гирлу р. Бистре, відповідності його національним інтересам, економічних та політичних інтересів Румуніï в цьому процесі, зазначимо, що висновки Комітету і Наради Сторін Орхуської конвенції та Конвенції Еспо стосувалися конкретно порушень 3 боку України як сторони багатосторонньої природоохоронної угоди, які вона брала на себе, 
підписуючи, а потім надаючи згоду на обов'язковість для себе цього міжнародного договору, зобов'язань щодо приведення національного законодавства у відповідність з положеннями Конвенції Еспо та Орхуської конвенції, проведення оцінку впливу на навколишнє середовище у транскордонному контексті, забезпечення участі громадськості в процесі ухвалення рішень з екологічних питань та надання ӥй доступу до екологічної інформації. Дотримання висновків органів цих екологічних конвенцій, без сумніву, покращить імідж держави України як у світі, так і у власному суспільстві, сприятиме ефективній реалізації зазначеного багатостороннього природоохоронного договору. Відповідні міркування стосуються й справи щодо продовження експлуатації енергоблоків № 1, 2 Рівненської АЕС.

Зростання кількості екологічних викликів в Україні об'єктивно вимагає неухильного дотримання основних вимог щодо захисту екологічних прав людини, закріплених у міжнародному праві.

Про незадовільний стан реалізаичї Орхуської конвенції та Конвенияї Еспо в Україні яскраво свідчить рішення, ухвалені Нарадою Сторін про невиконання їх положень.

У статті досліджені справи щодо проєкту з відновлення глибоководного суднового каналу по гирлу р. Бистре та щодо продовження експлуатаціі енергоблоків № 1, 2 Рівненської АEC.

Перша справа стосувалась обов'язку України, як держави, яка плануе діяльність, що може мати негативний вплив на навколишне середовище інших держав, повідомити Румунію про ие, надати необхідну документацію, провести консультаціі та переговори з циих питань, проінформувати громадськість та врахувати думку протилежної сторони за Конвенцією
Ecпо. У результаті дані порущення не були усунені. Також Україна порушила положення Орхуської конвенції шоодо участі громадськості у прийнятті рішень з конкретних видів діяльності. Зрештою, за иією справою Україна отримала позитивний висновок.

Що стосується експлуатаиіі енергоблоків № 1, 2 Рівненської АEC, то Україна не застосувала положення Конвениї Еспо до процедури видачі дозволу для продовження терміну експлуатаціі, а також не надала звіт про ОВД до видачі дозволу на продовження терміну експлуатаціі ядерних реакторів. Ця справа ще перебуває на розгляді Hаради Cmopiн Конвениї Eспо.

таким чином, розгляд справ проти України засвідчує, що, беручи на себе міжнародно-правові зобов'язання, держава повинна оцінити власні можливості щодо іх впровадження у внутрішню правову систему, включаючи забезпечення ефективного контролю за дотриманням положень багатосторонніх природоохоронних угод фізичними та юридичними особами, які перебувають під ї̈ юрисдикuією.

Ключові слова: екологічні права людини, Орхуська конвенція, Конвенції Еспо.

Lykhohliad V. Failure to comply with international standards for the protection of environmental human rights in cases concerning Ukraine under the Aarhus and the Espoo Conventions

The growing number of environmental challenges in Ukraine objectively requires strict compliance with the basic requirements for the protection of environmental human rights enshrined in international law.

The unsatisfactory state of implementation of the Aarhus Convention and Espoo Convention in Ukraine is clearly evidenced by the 
decisions adopted by the Meeting of the Parties to these agreements on non-compliance with their provisions.

The article examines the cases of the project for the restoration of the deep-water shipping canal at the mouth of the Bystre River and the continuation of the operation of power units № 1, 2 (Rivne NPP).

The first case concerned obligations of Ukraine, as a state planning activities that may have a negative impact on the environment of other states, to inform Romania, provide the necessary documentation, to hold consultations and negotiations on these issues to inform the public and take into account the views of the other party under the Espoo Convention. As a result, these violations were not eliminated. Ukraine has also violated the provisions of the Aarhus Convention on public participation in decision-making on specific activities. Finally, Ukraine received a positive conclusion in this case.

With regard to the operation of units № 1, 2 of the Rivne NPP, Ukraine did not apply the provisions of the Espoo Convention to the procedure for issuing a permit to extend the service life, nor did it submit a report on the environmental impact assessment before issuing a permit to extend the service life of nuclear reactors. This case is still pending before the Meeting of the Parties to the Espoo Convention.

Thus, the consideration of cases against Ukraine shows that, assuming international legal obligations, the state must assess its own ability to implement them in the domestic legal system, including ensuring effective control over compliance with multilateral environmental agreements by individuals and legal entities under its jurisdiction.

Key words: environmental human rights, Aarhus Convention, Espoo Conventions.

\section{Література}

1. The Aarhus Convention: An Implementation Guide (second edition). United Nations, 2014. URL: https: / / wrw. unece.org/env/pp/implementation_guide. html.

2. Прийняття Конвенції про оичнку впливу на навколишне середовище у транскордонному контексті. URL: http:// www.ecoleague.net / forumy-konferentsiikruhli-stoly-seminary/ekolohichnyi-kalendar/ liutyi / item / 295-pryiniattia-konventsiipro-otsinku-vplyvu-na-navkolyshnieseredovyshche-u-transkordonnomu-konteksti.

3. Конвенція про оцінку впливу на навколишне середовище у транскордонному контексті. URL: https:// zakon.rada.gov.ua/laws/show/995_272\# Text.

4. Медведева М.О. Інформаційно-правові засоби реалізації міжнародно-правових норм у галузі охорони навколишнього середовища. Актуальні проблеми держави і права. 2011, Bun. 62. C. 333-340.

5. Case EIA/IC/S/1 bis - Romania us. Ukraine /interactivel. URL: http:// www.unece.org/env/eia/implementation/ eia_ic_s_1.html.

6. Report of the Compliance Committee of the Aarhus Convention on Its Thirtyfirst Meeting. Addendum, p. 5 [interactive]. URL: http: / / wwr.unece.org / fileadmin / $D A M / e n v / p p / c o m p l i a n c e / C C-31 /$ ece_ mp.pp_c.1_2011_2_add.9_adv\%20edited .pdf.

7. Findings and recommendations further to a submission by Romania regarding Ukraine (EIA/IC/S/1). URL: https:// unece.org / DAM / env / documents / 2008/ eia/ ece.mp.eia.2008.6.e.pdf.

8. Report of the Fourth Meeting of the Parties (ECE/MP.EIA/10), para. 43. URL: http: / / www.unece.org / fileadmin/ DAM / env/documents / 2008 / eia/ece. mp.eia.10.e.pdf.

9. Letter to Mr Nemyrya, Deputy Prime Minister of Ukraine, from Mr Kubis, Executive Secretary of UNECE. URL: http: / / www. unece.org/fileadmin/DAM / env/eia/ documents / ImplementationCommittee / eia.ic.s / eia.ic.s.1/Letter_by_Mr_Kubis_to_ Mr_Nemyrya_20_Mar_09.pdf.

10. Report by the Meeting of the Parties at Its Fifth Session (ECE/ MP.EIA/15), Decision V/4. URL: http:// www.unece.org / fileadmin / DAM / env / documents / 2011 / eia/decision.V.4.e.pdf.

11. Седьмое Совещание Сторон Конвеничии об оценке воздействия на окружаю- 
щую среду в трансграничном контексте. URL: http: / / staging2.unece.org.net4all.ch / fileadmin / DAM / env / documents / 2017/ EIA/MOP7/01_05_17_ece_mp_eia_2017_4_ ece_mp.eia_sea_2017_4_r.pdf.

12. Meeting of the Parties to the Espoo Convention, 8th session. URL: https:// unece.org / environmental-policy / events / meeting-parties-espoo-convention-8thsession-and-meeting-parties.

13. Медведєва М.О. Реалізація міжнародних стандартів із забезпечення прочесуальних екологічних прав людини в Украіні. Наукові записки НаУКМА. 2014 Том 155. Юридичні науки. С. 49-51.

14. Доклад о работе Второго Совешания Сторон, решение II/5b «Соблюдение Украиной своих обязательств по Орхусской конвенции». ЕЭК ООН, ECE/ MP.PP/2005/2/Add.8, 13 June 2005. URL: http: / / www.unece.org / index.php?eID=tx_ nawsecuredl\&u=0\&file=fileadmin / DAM / env / documents / 2005 / pp / ece / ece.mp.pp.20 05.2.add.8.r.pdf\&t $=1322644819 \&$ hash $=$ da91f9 4c89acccf804520d93ee9715 $20704 a 74 f 2$.

15. Доклад о работе Третьего Совещания Сторон, решение III / $6 f$ «Соблюдение Украиной своих обязательств по Конвенuuu». EЭK OOH, ECE/MP. PP/2008/2/ Add.14, 26 September 2008. URL: http: / / w w. unece.org / index.php? eI D=tx. nawsecuredl\&u=0\&file=fileadmin / DAM / env/pp / compliance / MoP3decisions / Ukraine/ece_mp_pp_2008_2_add_14_r_
UkraineODS.pdf\&t $=1322645032 \&$ hash $=442$ c5a7d77eeae60c58865694124a735009b 539a

16. Алексєєва Є. I знову про Оргуську конвениію та невиконання Україною своїх зобов'язань. Екологія. Право. Людина. 2009. № 4-5. С. 53-56.

17. Украину вычеркнули из списка нарушителей Орхусской конвенции ООН - Минnpupodøl. URL: https://wrer.unian.net/ ecology / naturalresources / 2136754-ukrainuvyicherknuli-iz-spiska-narushiteleyorhusskoy-konventsii-oon-minprirodyi.html.

18. Як забезпечити дотримання $\mathrm{Koн-}$ вениії Еспо в ядерній сфері в Україні. URL: https: / / www.rac.org.ua/uploads / content / 77 / files / finalveb.pdf.

19. Supporting Information: Violations by Ukraine of its obligations under Espoo Convention in relation to extension of the lifetime of 1 st and 2 nd nuclear reactor of Rivne NPP. URL: https:// unece.org/ DAM / env/documents / 2019 / ece / Restart/CI_Ukraine/2._Supporting_Information_3.0_FINAL.pdf.

20. Представники України обрані до Комітету з дотримання Конвенції Ecno. URL: https: //wrw.kmu.gov.ua/ news / 247380203.

21. Седьмое Совемание Сторон Конвениии об оценке воздействия на окружающую среду в трансграничном контексте. URL: https: / / unece.org / DAM/env/documents / 2017 / EIA / MOP7 / 01_05_17_ece_mp_ eia_2017_4_ece_mp.eia_sea_2017_4_r.pdf . 